\title{
A Biography of Kenneth C. Land: Pioneer in Quality of Life and Social Indicators Research
}

\author{
Vicki L. Lamb
}

Received: 2 June 2014 / Accepted: 9 June 2014 / Published online: 19 June 2014

(C) Springer Science+Business Media Dordrecht and The International Society for Quality-of-Life Studies (ISQOLS) 2014

Kenneth C. Land was born in the small town of Llano, Texas (population 3,000) on August 19, 1942. He earned Bachelor of Arts degrees in Sociology and History at Texas Lutheran College in 1964, a Master of Arts degree in Sociology, minoring in Mathematics, from the University of Texas-Austin in 1966, and a Ph. D. in Sociology, minoring in Mathematics, from the University of Texas-Austin in 1969. He was a Social Science Research Council Postdoctoral Fellow in Mathematical Statistics at Columbia University from 1969-1970. And later Ken was successively a member of the faculties of the University of Illinois at Urbana Champaign and the University of Texas at Austin before joining the Duke Sociology Department as Chairman, which he served from January 1986 to August 1997. Ken was named the John Franklin Crowell Professor of Sociology and Demography at Duke University in 1990.

Ken's contributions to social indicators/quality-of-life/well-being studies commenced during his Social Science Research Council Post-Doctoral Fellowship year at Columbia University. Dr. Eleanor Sheldon of the Russell Sage Foundation had initiated the Indicators of Social Change research project at the Foundation. She interviewed Ken and signed him up to work on the project on a part-time basis during the PostDoctoral year and then as a Staff Member of the Foundation for 3 years after that.

The first product of Ken's work at Russell Sage was the article "On the Definition of Social Indicators (1971)." In this article Ken, outlined the characteristics of social indicators, and specified that "... the criterion for classifying a social statistic as a social indicator is its informative value which derives from its empirically verified nexus in a conceptualization of a social process" (p. 323, emphasis in original).

Pursuing this line of thought, in the 1970s and 1980s Ken organized a number of conferences and workshops to focus on the use of social indicators, and each resulted in an edited volume of the work presented. He and sociologist Seymour Spilerman coordinated a Russell Sage Foundation-sponsored Conference on Social Indicators Models, to explore models that could be used to form indicators of the functioning of social systems and analyze their interconnections and changes over time. As a member

V. L. Lamb (凹)

North Carolina Central University, 1801 Fayetteville St, Durham, NC 27707, USA

e-mail: vlamb@nccu.edu 
of the Social Science Research Council Advisory and Planning Committee on Social Indicators from 1976-1982, Ken and economist F. Thomas Juster coordinated a Workshop on Social Accounting Systems that explored recent developments in demographic accounts, time-use accounts, and well-being accounts to complement and update the National Income and Product Accounts. When the Advisory Committee focused on the topic of forecasting social indicators and social change, Ken coordinated a conference with weather scientist Stephen H. Schneider in 1984, which brought together social and natural scientists to focus on problems of forecasting in large-scale, interactive, non-linear systems. Each of these conferences led to edited volumes on the topics, cited in the Selected References.

Throughout his career Ken has used social indicators and forecasting to study trends in a variety of topics, including crime, employment and occupations, marriage and family, and social/economic planning. He has been the recipient of a number of prestigious awards, including the 1997 Paul F Lazarsfeld Award from the Methodology Section of the American Sociological Association, the 2003 Distinguished Service Award from the International Society for Quality-of-Life Studies (ISQOLS), and the 2010 Distinguished QOL Researcher Award from ISQOLS. Ken has served many officer positions in regional, national, and international organizations, including President of the Southern Sociological Society, 2000-2001, President of ISQOLS, 2001-2002, and President of the International Sociological Association Working Group on Social Indicators and Social Reporting, 2002-2006. Since 1996, Ken has been editor of Social Indicators Network News (SINET), a position that was previously held by another QOL Pioneer, Abbott Ferriss.

All of the foregoing work established Ken as the "go-to" American sociologist for research on social indicators in the 1990s. Pursuant to this, Dr. Ruby Takanishi, President of the Foundation for Child Development (FCD) approached Ken in 1997 with the question of what could be done to better track and study changes in the lives of children and young people in American society. At the time there were numerous statistical indicators of child and youth well-being. Dr. Takanishi asked, "Can you (Ken) do something to put the indicators together and give us a sense of overall changes in well-being?" Ken took on this challenge and, working with me (at the time a PostDoctoral Fellow at Duke) and several Duke University doctoral students, has worked on the FCD Child and Youth Well-Being Index Project since 1998.

The centerpiece of the Project is the FCD Child and Youth Well-Being Index (CWI). The CWI initially was developed in articles published in 2001 (Land, Lamb, and Mustillo) and 2007 (Land, Lamb, Meadows, and Taylor). Building on the social indicators and quality-of-life research literature we identified seven domains of wellbeing: Family Economic Well-Being, Health, Safe/Risky Behavior, Educational Attainment, Community Engagement, Social Relationships (with Family and Peers), and Emotional/Spiritual Well-Being. We then identified 28 social indicators for which there were national statistical time series in annual or other periodic intervals, most dating back to 1975 . Each of the 28 social indicators was assigned to one of the seven domains.

When Ken created the Child and Youth Well-Being Index, the year 1975 was used as the base year value for each indicator. Using the values of each indicator for subsequent years, we calculated the percentage change from the base year value. We then averaged the percent change within each of the seven domains, and then averaged 
the percent change in the seven domains to produce the overall CWI. The CWI thus can be viewed as a composite measure of trends in the quality of life, or well-being, of America's children and young people since the base year. This project has been quite productive in tracking both overall trends in child and youth well-being as well as drawing attention to trends for specific domains or indicators. In 2012, Ken edited a volume encompassing our work on child and youth well-being.

When we started the project, there was no compelling research regarding how to assign values or weights for the seven domains, so we used equal weighting throughout to create the CWI. Ken, putting on his statistician's cap, worked with Michael Hagerty on a methodological article (Hagerty and Land 2007) that studied the statistical properties of the equal weights estimator that assigns equal weights to all indicators averaged into a composite social indicator. They showed, both analytically with mathematical proofs and numerically with simulations, that the equal weights estimator is what statisticians call a minimax estimator, in the sense that it minimizes extreme disagreements among individuals with respect to the weights that should be used.

Suffice it to say that the conceptual and methodological innovations in the measurement of trends in well-being developed in the FCD-CWI Project have been substantial and have influenced a considerable amount of related research in well-being outcomes. Although Ken will become an emeritus professor in July 2014, there is no doubt that he will continue to be influential in the study of social indicators, quality of life, and forecasting. I look forward to our continued work together.

\section{References}

Edited Books

Evans, M. D., Felson, M., \& Land, K. C. (1980). Developing social indicator research on the military in American Society. Social Indicators Research, 8(March), 81-102.

F. Thomas Juster and Kenneth C. Land (eds.). 1981. Social Accounting Systems: Essays on the State of the Art. New York: Academic Press, Studies in Population Series

Hagerty, M. R., \& Land, K. C. (2007). Constructing summary indices of quality of life: a model for the effect of heterogeneous importance weights. Sociological Methods Research, 35(May), 455-496.

Invited Chapters and Other Contributions to Volumes (not edited by Ken Land)

Kenneth C. Land, 2001. "Models and Indicators," Social Forces, 80, (December):381-410. [Ken's Presidential Address to the Southern Sociological Society]

Land, K. C. (1971). On the definition of social indicators. The American Sociologist, 6(November), 322-325.

Land, K. C. (Ed.). (2012). The well-being of America's children: developing and improving the child and youth well-being index. New York: Springer.

Land, K. C., \& Felson, M. (1976). A general framework for building dynamic macro social indicator models: including an analysis of changes in crime rates and police expenditures. American Journal of Sociology, 82(November), 565-604.

Land, K. C., \& Felson, M. (1977). A dynamic macro social indicator model of changes in marriage, family, and population in the United States. Social Science Research, 6(December), 328-362.

Land, K. C., \& Schneider, S. H. (Eds.). (1987). Forecasting in the social and natural sciences. Boston: D. Reidel Publishing Company.

Land, K. C., \& Spilerman, S. (Eds.). (1975). Social indicator models. New York: Russell Sage.

Land, K. C., Lamb, V. L., \& Mustillo, S. K. (2001). Child and youth well-being in the United States, 19751998: some findings from a New index. Social Indicators Research, 56(December), 241-320.

Land, K. C., Lamb, V. L., Meadows, S. O., \& Taylor, A. (2007). Measuring trends in child well-being: an evidence-based approach. Social Indicators Research, 80(January), 105-132. 
Land, K. C., Lamb, V. L., \& Zheng, H. (2011). How Are the kids doing? How Do We know? recent trends in child and youth well-being in the United States and some international comparisons. Social Indicators Research, 100(February), 463-477.

Lee, J., Lamb, V. L., \& Land, K. C. (2009). Composite indices of changes in child and youth well-being in the San Francisco Bay area and the state of California, 1995-2005. Child Indicators Research, 2(December), 353-374.

Meadows, S. O., Land, K. C., \& Lamb, V. L. (2005). Assessing Gilligan versus Sommers: gender-specific trends in child and youth well-being in the United States. Social Indicators Research, 70(January), 1-52.

Michael, R., Hagerty Robert, A., Cummins Abbott, L., Ferriss Kenneth, L., Alex, C., Michalos Mark, P., Andrew, S., Joseph, S., \& Joachim, V. (2001). "Quality of Life Indexes for National Policy: Review and Agenda for Research,”. Social Indicators Research, 55, 1-96.

O’Hare, W. P., Mather, M., Dupuis, G., Land, K. C., Lamb, V. L., \& Qiang, F. (2013). Analyzing differences in child well-being among U.S. States. Child Indicators Research, 6(June), 401-413.

Pampel, F. C., Land, K. C., \& Felson, M. (1977). A social indicator model of changes in the occupational structure of the United States: 1947-74. American Sociological Review, 42(December), 951-964.

Peer-Reviewed Publications

Vicki, L., \& Kenneth, C. (2013). "Methodologies Used in the Construction of Composite Child Well-Being Indices.”. In A. Ben-Arieh, F. Casas, I. Frones, \& J. Korbin (Eds.), Handbook of Child Well-Being (pp. 2739-2755). New York: Springer.

Vicki, L., Kenneth, C., Land, S., Meadows, O., \& Fasaha, T. (2005). "Trends in African-American Child WellBeing: 1985-2001.”. In C. Vonnie, N. McLoyd, E. Hill, \& A. Kenneth (Eds.), African American Family Life: Ecological and Cultural Diversity (pp. 45-77). New York: Guilford Publications.

Vicki L. Lamb and Kenneth C. Land, 2014. "Worldwide View of Child Well-Being." In Global Handbook of Well-Being and Quality of Life, Wolfgang Glatzer (ed.). New York: Spinger, forthcoming. 